\title{
Isolation, Purification and Antimicrobial Efficacy of Ovotransferrin from Eggs of Broiler, Domestic and Quail
}

\author{
Sampath Kumar $\mathrm{G}^{1}$, Anitha ${ }^{1}$, Preethi L², Arunkumar R ${ }^{3}$, Ilakkiya $\mathrm{A}^{\# 1}$, Selvakumar $\mathrm{K}^{4 *}$ \\ ${ }^{1 \# A s s t . ~ P r o f e s s o r, ~}{ }^{1}$ Department of Biochemistry, Vel's Institute of Science, Technology \& Advanced Studies, \\ Pallavaram, Chennai, Tamil Nadu, India \\ ${ }^{2}$ Department of Genetics, Dr ALMPGIBMS, University of Madras, Taramani, Chennai - 600113 \\ ${ }^{3}$ Scientist, Department of Medical Research Unit, MMC, Chennai, Tamil Nadu, India \\ ${ }^{4}$ Head- Department of Clinical Biochemistry, Billroth Hospitals, Shenoy Nagar, Chennai Tamil Nadu, India \\ *Corresponding Author: Dr. Selvakumar Kandaswamy (bennysgod@gmail.com, drselvabillroth@gmail.com)
}

\begin{abstract}
Ovotransferrin is one of the major egg white proteins that have antimicrobial activity as well as iron binding capability. The objective of this study was to develop a simple and easy method to separate ovotransferrin using organic solvents. The purity of the ovotransferrin was determined using SDS-PAGE, the isolated protein was further studied for the assessment of interaction between food borne pathogens and the isolated Otrf by protein-protein molecular docking. However, this method is simpler and more cost effective than the previous method. The isolated ovotransferrin can be used as is or after modifications for various applications such as antimicrobial treatments. Recently, the iron chelating activity of Otrf has been exposed to upsurge the stimulus by an inhibitor of AMPc B-lactamase of some antibiotics which are efficient against most $B$-lactamaseproducing bacteria. Cefiderocol is a siderophore cephalosporin antibiotic that has recently been developed to combat a variety of bacterial pathogens, including $\beta$-lactam and carbapenem-resistant organisms. OtrF is currently recommended for use in conjunction with antibiotics unless further studies increase the effectiveness of OtrF. These studies highlight the separation, purification of potential diversity in antimicrobial efficacy of Otrf.
\end{abstract}

Keywords: Otrf, AMPC, SDS-PAGE

\section{INTRODUCTION}

Egg white contains many functionally important proteins from this consisting $12 \%$ of Ovotransferrin (Otrf), which is otherwise called as conalbumin, but was renamed as ovotransferrin after findings that it can bind iron, is a monomeric or iron- strap glycoprotein but the ovotransferrin produced was holo-form and needed to convert to apo-form if it was intended to be used as an antimicrobial agent. The high affinity of Otrf for iron implies that in the presence of unsaturated Otrf (apo-Otrf), iron will be sequestered and rendered unavailable for the growth of microorganisms. ${ }^{[1,2]}$ Currently, egg white proteins encompass adequate industrial contribute, and costeffective purification procedures need to be develop for production of Otrf from egg white proteins [3], which donate to large-scale commercial production of Otrf, However, the practical use of egg proteins by industry is highly limited. Separation of egg white proteins were done for many years but still new, simple, economical, and sequential methods with 
better yield and purity are emerging. Otrf plays a essential physiological and immunomodulatory role while embryogenesis. ${ }^{[4]}$ Due to its ability to chelate iron, an necessary compound for bacterial growth, ${ }^{[5,6]}$ Otrf perform as a bacteriostatic, along with may possibly act as a bactericide by damaging the bacterial cytoplasmic membrane, iron $\left(\mathrm{Fe}^{2+}\right.$ or $\left.\mathrm{Fe}^{3+}\right)$-binding protein 'transferrin' in ovotransferrin put forth antimicrobial activity. ${ }^{[7]}$

Otrf was the essential component of the egg's antimicrobial defense system. The antimicrobial potency of egg albumin was boosted at alkaline $\mathrm{pH}$ condition ( $\mathrm{pH} 9.5$ ) and by temperature near $40^{\circ} \mathrm{C}$, the physiological temperature of birds. ${ }^{[8]}$ It was evident that saturation of Otrf, by iron supplement of egg albumin at $39.5^{\circ} \mathrm{C}$, does not convert hen egg albumin into an optimal medium for the growth of E. coli. It is now clearly established that Otrf possesses both the bacterial growth inhibition (static) and the iron withholding-independent (cidal) and antimicrobial actions. Exertion of a particular antimicrobial action seems to be environment-dependent and microorganism specific. However, many microorganisms are able to acquire iron bound to transferrins, including Otrf. ${ }^{[9]}$

Microorganisms achieve this via dual types of empirical mechanisms. One functions done by making of high affinity iron chelators (called siderophores) capable of eliminating iron since transferrin and transporting it to the cell via siderophore-receptors on the cell surface, second mechanism is by stating a receptor for the transferrin itself by which the bacteria can then remove the iron through a mechanism usually linking outer membrane and periplasmic iron transport proteins. ${ }^{[10,11]}$ Recently, the iron chelating activity of Otrf has been exposed to upsurge the stimulus by an inhibitor of AMPc ß-lactamase of some antibiotics which are efficient against most $B$-lactamase- producing bacteria. ${ }^{[12]}$ Otrf hence seems as a key aspect for drug connotations clever to overcome the cephalosporin resistance. ${ }^{[13]}$ Cefiderocol is a siderophore cephalosporin antibiotic that has recently been developed to combat a variety of bacterial pathogens, including $\beta$-lactam and carbapenemresistant organisms. Resistance is a natural phenomenon, and it is inevitable that it will progress to all antibiotics at some time. As misuse and overuse of antibiotics accelerate the development of resistance, ${ }^{[14]}$ antibiotics should be used more responsibly and new antibacterial treatments should be developed to counteract emerging resistance. However, there are challenges, which are both scientific - for the discovery of new antibiotics - and economic -for ensuring investment into research and development. ${ }^{[15]}$ In recent years, political commitment to combat antimicrobial resistance has increased significantly at global, regional and national levels. In 2015, the Sixty-eighth World Health Assembly endorsed the Global Action Plan on antimicrobial resistance. ${ }^{[16]}$

The priorities for combatting antimicrobial resistance. Cefiderocol is novel in its approach to overcoming the three main mechanisms of antibiotic resistance used by both Gram negative and positive bacteria -- two outer membranes that make it hard for antibiotics to penetrate, porin channels which can adapt and change to block the antibiotic entry, and efflux pumps that expel antibiotics back out of the cell and make the drugs ineffective. Cefiderocol uses a novel mechanism of cell entry that takes advantage of the bacteria's need for iron to survive. During an acute infection, one of our innate immune responses is to create an iron-poor environment. In response, bacteria increase their iron intake. Cefiderocol binds to irons and is transported through the extra outer membrane by the bacterium's own iron-transport system. These iron channels also enable the drug to bypass the bacteria's porin channels and gain repeat 
entry even if the bacterium has evolved efflux pumps." $[17,18,19]$

Father of medicine Hippocrates words "Leave your drugs in the chemist's pot, if you can heal the patient with food". Chemicals are more susceptible to adverse an effect which creates a mischief to the body. Our study suggests the use ovotransferrin as alternative ailment by using future investigations. This study was remembers the hippocrate words that is "Natural forces within us are the true healers of disease" OtrF is currently recommended for use in conjunction with antibiotics unless further studies increase the effectiveness of OtrF. These studies highlight the separation, purification and potential diversity in antimicrobial efficacy and mechanism of action for Otrf.

\section{METHODS AND MATERIAL}

\section{EGGS}

The eggs of domestic hen, broiler hen and quail egg were procured from the local market and performed on the same day.

\section{CHEMICALS}

All chemicals used in this study were procured from SRL, Medox, Sigma Aldrich (USA) and Hi- Media laboratories (India).

\section{SEPARATION OF ALBUMEN}

The egg white was carefully removed from the egg yolk.

\section{SEPARATION OF OVOTRANSFERRIN}

Diluted with Equal volume of distilled water $\rightarrow$ Homogenized using a hand mixer $\rightarrow$ The $\mathrm{pH}$ was adjusted to 4.5 to 5.0 using $3 \mathrm{NHCl} \rightarrow$ Centrifuged at $3,400 \times g$ for $30 \mathrm{~min}$ at $4^{\circ} \mathrm{C} \rightarrow$ Collect the supernatant and add 5\% (wt/vol) ammonium sulfate and $2.5 \%$ (wt/vol) citric acid combinations and keep overnight $\rightarrow$ Centrifuged at $3,400 \times g$ for $20 \mathrm{~min}$ at $4^{\circ} \mathrm{C}$. Collect precipitant, dissolved with 2 volumes of DW $\rightarrow$ Desalt, Add $2.0 \%$ (wt/vol) ammonium sulfate and $1.5 \%$ (wt/vol) citric acid combinations and keep overnight $\rightarrow$ Centrifuged at $3,400 \times g$ for $20 \mathrm{~min}$ at $4^{\circ} \mathrm{C}$. The precipitant was measured and dissolved with 2 volumes of DW and then desalted $\rightarrow$ Freeze dry.

\section{VERIFICATION OF OVOTRANSFERRIN BY SDS PAGE}

SDS-PAGE used to check the purity of samples. An overall examination of the isolation of ovotransferrin isolated and purified egg albumin. Ovotransferrin were extracted from egg albumin and separated on $10 \%$ polyacrylamide gel on the basis of size/charge. The protein was visually identified by coomassie blue staining; the protein was identified by the low molecular weight marker.

\section{ASSESSMENT OF ANTIMICROBIAL ACTIVITY OF OVOTRANFERRIN}

\section{BACTERIAL STRAINS}

Bacterial strains Staphylococcus aureus (ATCC) and Shigella (ATCC) were purchased form Hi- Media laboratories.

\section{CULTURE MEDIUM AND INOCULUM PREPARATION}

High sensitivity testing agar (Hi-Media) was used for checking antibacterial activity of Ovotransferrin isolated from different egg whites of domestic hen, broiler hen and quail, against Staphylococcus aureus and shigella. The microbial strains were procured from American Type Culture Collection (ATCC). The microbial strains were cultured on the slants in the sterilized Laminar Air Flow from the pure culture. These cultured slants were incubated at $37^{\circ} \mathrm{C}$ for bacterial growth for 2-3 days. 


\section{PREPARATION OF BRAIN HEART INFUSION BROTH}

Suspended $37 \mathrm{gms}$ in $1000 \mathrm{ml}$ of distilled water. Heat if it is necessary to dissolve the medium completely and dispend the medium on to the bottles and tubes. Sterilized by autoclave at $15 \mathrm{lbs}$ at $121^{\circ} \mathrm{C}$ for 15 minutes.

\section{MOLECULAR PROTEIN - PROTEIN DOCKING STUDIES USING CLUSPRO SOFTWARE}

The ClusPro server (https://cluspro.org) is a widely used tool for protein-protein docking. The server provides a simple home page for basic use, requiring only two files in Protein Data Bank (PDB) format. However, ClusPro also offers a number of advanced options to modify the search; these include the removal of unstructured protein regions, application of attraction or repulsion, accounting for pairwise distance restraints, construction of homo-multimers, consideration of small-angle $\mathrm{X}$-ray scattering (SASAXS) data, and location of heparin-binding sites. Six different energy functions can be used, depending on the type of protein.

Docking with each energy parameter set results in ten models defined by centres of highly populated clusters of low-energy docked structures. This protocol describes the use of the various options, the construction of auxiliary restraints files, the selection of the energy parameters, and the analysis of the results. Although the server is heavily used, runs are generally completed in $<4 \mathrm{~h}$.

\section{RESULTS AND DISCUSSION}

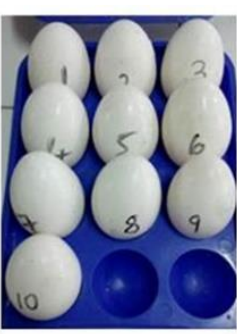

Broiler Chicken Eggs

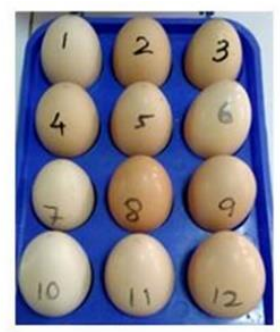

Domestic chicken Egg

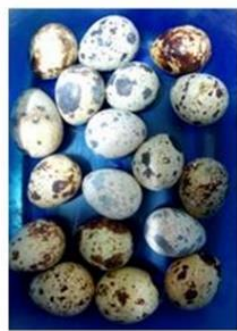

Quail Eggs
FIG 1: SEPARATION OF ALBUMEN FROM WHOLE EGG OF BROILER CHICKENS (GALLUS GALLUS DOMESTICUS), DOMESTIC CHICKEN (GALLUS GALLUS), QUAIL EGG (COTURNIX COTURNIX) Whole egg of broiler, Domestic and Quail eggs were procured from the local market and it was broken gently in a petri dish and the whole albumen was collected using a syringe without disturbing the vitelline membrane of the yolk
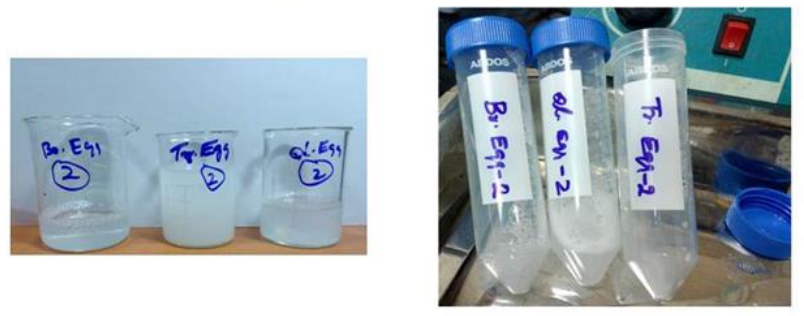

Figure 2 shows isolation of ovotransferrin from albumin from $\mathrm{BrE}$ : Broiler Egg, Tr: Domestic Egg, QlE: Quail egg.

FIG: 2. ISOLATION OF OVOTRANSFERRIN FROM ALBUMEN OF BROILER CHICKENS (GALLUS GALLUS DOMESTICUS), DOMESTIC CHICKEN (GALLUS GALLUS), QUAIL EGG (COTURNIX COTURNIX) BY SUCTION PUMP FILTRATION USING $2 \mu$ FILTER

Ovotransferrin was isolated from the albumen of broiler chickens (Gallus gallus domesticus), domestic chicken (Gallus gallus), Quail egg (Coturnix coturnix) by suction pump filtration. The volume obtained from this isolation is around $5-10$ $\mathrm{ml}$ 


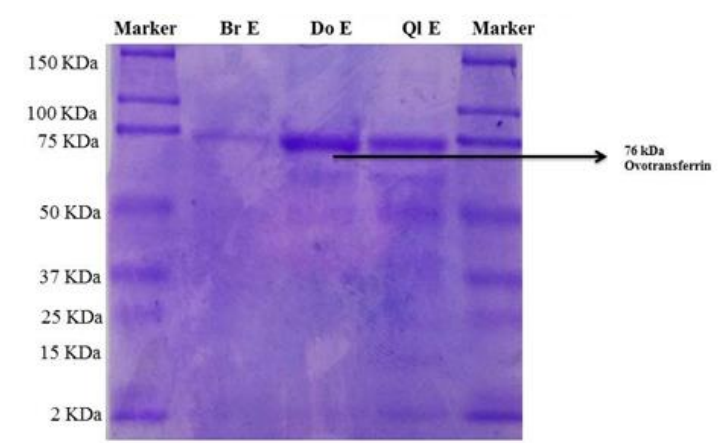

The SDS PAGE of egg white proteins collecte from BrE : Broiler Egg, DoE: Domestic Egg, QIE: Quail Egg over the sepration step of the apo form of ovotransferrin using a low level combination of ammonium sulphate and citric acid. Lane 1 showed marker, Lane $2 \mathrm{BrE}$, Lane 3 DoE, Lane 4 Q1E. About $76 \mathrm{kDa}$ of Ovatransferrin was isolated

\section{FIG: 3. VALIDATION AND CONFIRMATION OF} ISOLATED OVOTRANSFERRIN BY SDS PAGE STAINNED USING COOMASSIE BRILLIANT BLUE

Isolated ovotransferrin was validated and confirmed using the sodium dodecyl sulfate polyacrylamide gel electrophoresis (SDS PAGE) and the protein was stained using Coomassie brilliant blue, the protein was confirmed using a BIO-RAD prestained low range protein marker. The result shows contend of isolated ovatransferrin was high on domestic chicken eggs while compare with broiler eggs and quail eggs.
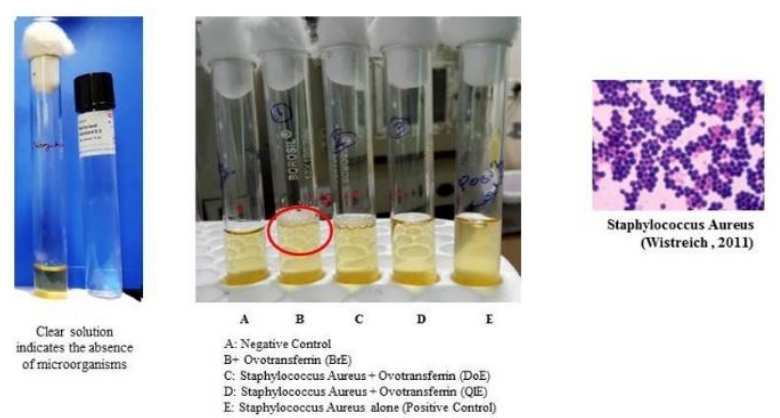

BHI- broth diffusion method using $0.5 \mathrm{Mc}$ farland standard as a negative control

FIG 4. A \& B. ANALYSIS OF ANTI-

MICROBIAL ACTIVITY OF ISOLATED

OVOTANSFERRIN ON FOOD BORNE

\section{PATHOGENS}

Isolated ovotransferrin was used to analysed antimicrobial property on food borne pathogens such as Staphylococcus Aureus (Fig 4A) and Shigella (Fig 4B). The bacteria were procured from ATCC- USA and it was incubated with the isolated protein on BHI- broth diffusion method using 0.5 Mc farland standard as a negative control. The result shows no turbidity which indicates the Ovatransferrin act as anti-microbial agent on Staphylococcus Aureus (Fig 4A) and Shigella (Fig 4B).

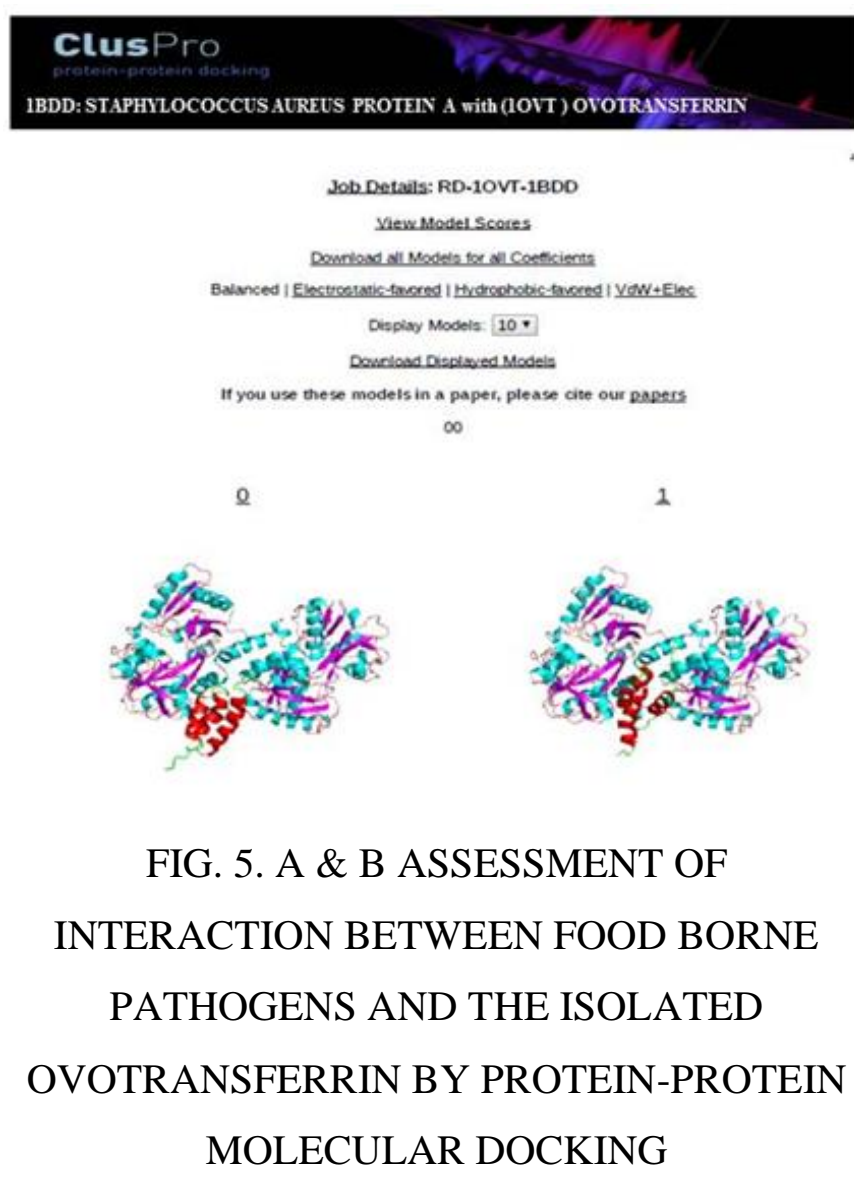




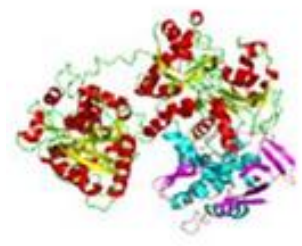

4

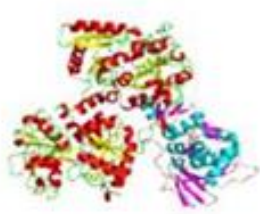

6

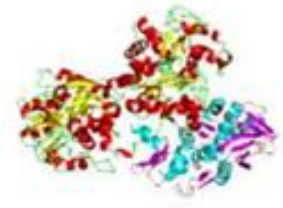

8
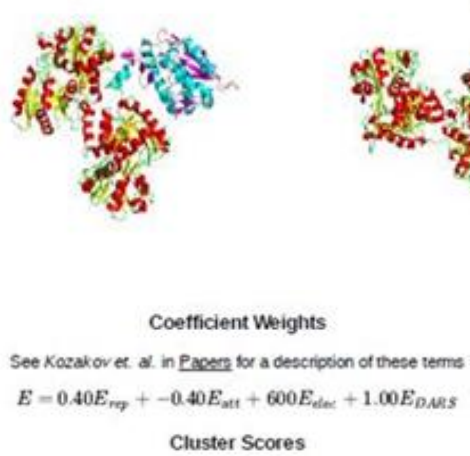

Cluster Scores

We strongly encourage you to read the FAO relacod ro these scoces betre using them

\begin{tabular}{|c|c|c|c|}
\hline Guser & Members & Representative & Weighted Score \\
\hline \multirow[t]{2}{*}{0} & \multirow[t]{2}{*}{63} & Certer & 605.8 \\
\hline & & Lowest Energy & 670.2 \\
\hline \multirow[t]{2}{*}{1} & \multirow[t]{2}{*}{57} & Certer & 6847 \\
\hline & & Lowest Energy & -735.3 \\
\hline \multirow[t]{2}{*}{2} & \multirow[t]{2}{*}{42} & Certer & -7190 \\
\hline & & Lowest Eneryy & -769.6 \\
\hline \multirow[t]{2}{*}{3} & \multirow[t]{2}{*}{41} & Center & -707.0 \\
\hline & & Lowest Energy & .707 .0 \\
\hline \multirow[t]{2}{*}{4} & \multirow[t]{2}{*}{38} & Cerner & -5943 \\
\hline & & Lowest Energy & -7729 \\
\hline \multirow[t]{2}{*}{5} & \multirow[t]{2}{*}{31} & Center & -768.4 \\
\hline & & Lowest Energy & .796 .4 \\
\hline \multirow[t]{2}{*}{6} & \multirow[t]{2}{*}{28} & Certer & -6739 \\
\hline & & Lowest Energy & -690.9 \\
\hline
\end{tabular}

Low-energy regions tend to generate large clusters of docked structures, and the size of a cluster is approximately proportional to its probability, and thus the energy landscape indirectly determines the most likely conformation of the complex.
The isolated protein was further studied for the assessment of interaction between food borne pathogens and the isolated Otrf by protein-protein molecular docking using Cluspro software. The protein of 1BDD: staphylococcus aureus protein-A with (1OVT) Otrf was docked for the protein- protein interaction. The protein was docked 10 cycles and it was analysed for cluster formation and the lower energy affinity. The result shows the low-energy regions which tend to generate large clusters of docked structures, and the size of a cluster is approximately proportional to its probability, and thus the energy landscape indirectly determines the most likely conformation of the complex.

\section{DISCUSSION}

Egg contains many functional proteins, and their functional properties are very well known. However, the practical use of egg proteins by industry is highly limited. Separation of egg white proteins were done for many years but still new, simple, economical, and sequential methods with better yield and purity are emerging. If the separated proteins are mainly targeted for use in food and pharmaceutical industries to increase their values, however, the separation protocol should not use toxic chemicals. Among the egg white proteins, ovotransferrin as an antimicrobial agent or iron carrier, the industrial applications of egg white proteins as well as their enzyme hydrolysates are in their infant stage even though some research on the use of egg proteins has been published in recent years. ${ }^{[20,21]}$

In this study the main principle used in that when the $\mathrm{pH}$ value of a protein solution changes, the charges on the amino acid side chains in a protein change. Therefore, the precipitation behaviour of a protein in ammonium sulfate solution can be changed. It is known from large-scale separation of protein trials that altering the $\mathrm{pH}$ of a solution by acid or alkali can increase the ionic strength of a solution and change 
polarity of proteins, resulting in easy precipitation of proteins. ${ }^{[22]}$ Saturated ammonium sulfate with acidic condition was used to separate egg white proteins in early 1900s. ${ }^{[23,24]}$ Therefore, the first approach was testing how Otrf is behaving under different ammonium sulfate and acid conditions. Acetic acid and citric acids are the 2 most common organic acids that can be added in foods, and thus the effects of acetic acid or citric acid and ammonium sulfate combinations in precipitating Otrf in egg white were tested. The amount and purity of proteins precipitated indicated that ammonium sulfate + citric acid performed better than ammonium sulfate + acetic acid in separating Otrf. Therefore, citric acid was used as the acid for ovotransferrin separation. $5.0 \%$ (wt/vol) ammonium sulfate and $2.5 \%(\mathrm{wt} / \mathrm{vol})$ citric acid combination was selected as the best conditions to isolate ovotransferrin from egg white. Ammonium sulfate has a tendency to precipitate ovalbumin, also. With 5\% ammonium sulfate and $2.5 \%$ citric acid treatment, some ovalbumin was precipitated along with ovotransferrin. Thus, further purification was needed to remove ovalbumin from the crude ovotransferrin extract. ${ }^{[1]}$

The quail egg white proteome pattern seems closer related with that of chicken, which both belong to the Galliformes order. As the primary animal protein in many parts of the world, egg products will continue to be an important part of our daily diets; new technologies and new methods of egg processing such as non-thermal processing will see applications in the egg industry to improve nutrition, safety, shelflife and taste of egg products, or to create new egg products. ${ }^{[25]}$

Based on this study we are isolated the ovotransferrin and study was conducted to compare the antimicrobial activities of Ovotransferrin from 3 domestic avian species: Broiler chickens (Gallus gallus domesticus), Domestic chicken (Gallus gallus), Quail
Egg (Coturnix coturnix). Initially the ovotransferrin was separated and isolated and it was validated and confirmed using SDS PAGE, the result clearly depicts that isolated Ovatransferrin was high in domestic eggs while compare with the other species such as Broiler chickens (Gallus gallus domesticus), Quail Egg (Coturnix coturnix). This proves that the protein isolated form domestic egg is better than the Broiler and Quail.

Further study is to validate the isolated ovotransferrin by assessing the anti-microbial property on food borne pathogens such as Staphylococcus Aureus (Fig 4A) and Shigella (Fig 4B). The bacteria were procured from ATCC- USA and it was incubated with the isolated protein on BHI- broth diffusion method using 0.5 Mc Farland standards as a negative control. The result shows no turbidity on ovotransferrin isolated from the domestic egg, than Broiler eggs and Quail eggs, which indicates effective anti-microbial agent on Staphylococcus Aureus (Fig 4A) and Shigella (Fig $4 \mathrm{~B})$.

The isolated protein was further studied for proteinprotein molecular docking using Cluspro software. The protein of 1BDD: staphylococcus aureus proteinA with (1OVT) ovotransferrin was docked for the protein- protein interaction. The protein was docked 10 cycles and it was analysed for cluster formation and the lower energy affinity. The result shows the low-energy regions which tend to generate large clusters of docked structures, and the size of a cluster is approximately proportional to its probability, and thus the energy landscape indirectly determines the most likely conformation of the complex. The lower energy was high in Shigella while compare with staphylococcus aureus protein-A which shows the ovatransferrin will act as better antimicrobial agent on shigella than staphylococcus aureus protein-A 


\section{CONCLUSION}

The albumen was separated from the eggs of broiler chickens (Gallus gallus domesticus), domestic chicken (Gallus gallus), Quail egg (Coturnix coturnix). Ovotransferrin was isolated using suction pump on the separated albumen of Domestic eggs, Broiler chicken eggs and Quail eggs respectively. the separated ovotransferrin from domestic egg found to be better while compare with the other two species using SDS-PAGE and the isolated compound was further compared and analysed for antimicrobial activity on major food borne pathogens such as Staphylococcus Aureus and Shigella. The molecular studies were conducted for the protein-protein interaction using Cluspro molecular docking software. The docking studies were proved that ovotransferrin have a definite role and affinity to bind and inter act on pathogens.

In recent years, there has been a growing interest in researching and developing new antimicrobial agents from various sources to combat microbial resistance. Therefore a greater attention has been paid to antimicrobial activity screening and evaluating methods.

\section{ACKNOWLEDGEMENT}

The molecular docking study was supported by Dr Raghunandha Kumar, NPDF, Anna University is gratefully acknowledged.

\section{CONFLICTS OF INTEREST - Nil}

\section{REFERENCES}

[1]. Abeyrathne ED, Lee HY, Ahn DU. Egg white proteins and their potential use in food processing or as nutraceutical and pharmaceutical agents-A review. Poultry Science. 2013;92:3292-9.
[2]. Wei Z, Huang Q. Modification of ovotransferrin by Maillard reaction: Consequences for structure, fibrillation and emulsifying property of fibrils. Food Hydrocolloids. 2019;97:105186.

[3]. Ko KY, Ahn DU. An economic and simple purification procedure for the large-scale production of ovotransferrin from egg white. Poultry science. 2008;87:1441-50.

[4]. Giansanti F, Leboffe L, Pitari G, Ippoliti R, Antonini G. Physiological roles of ovotransferrin. Biochimica et Biophysica Acta (BBA)-General Subjects. 2012;1820:218-25.

[5]. Baron F, Jan S. Egg and egg product microbiology. InImproving the safety and quality of eggs and egg products. Woodhead Publishing. 2011;330-350.

[6]. Baron F, Jan S, Gonnet F, Pasco M, Jardin J, Giudici B, Gautier M, Guérin-Dubiard C, Nau F. Ovotransferrin plays a major role in the strong bactericidal effect of egg white against the Bacillus cereus group. Journal of food protection. 2014;77:955-62.

[7]. Ibrahim HR, Sugimoto Y, Aoki T. Ovotransferrin antimicrobial peptide (OTAP-92) kills bacteria through a membrane damage mechanism. Biochimica et Biophysica Acta (BBA)-General Subjects. 2000 ;1523:196-205.

[8]. Gupta RC, Srivastava A, Lall R, editors. Nutraceuticals in Veterinary Medicine. Springer; 2019.

[9]. Alabdeh M, Lechevalier V, Nau F, Gautier M, Cochet MF, Gonnet F, Jan S, Baron F. Role of incubation conditions and protein fraction on the antimicrobial activity of egg white against Salmonella Enteritidis and Escherichia coli. Journal of food protection. 2011;74::24.

[10]. Park RY, Choi MH, Sun HY, Shin SH. Production of catechol-siderophore and utilization of transferrin-bound iron in Bacillus cereus. Biological and Pharmaceutical Bulletin. 2005;28:1132-5.

[11]. Page MG. Siderophore conjugates. Annals of the New York Academy of Sciences. 2013;1277:11526. 
[12]. Babini GS, Livermore DM. Effect of conalbumin on the activity of Syn 2190, a 1, 5 dihydroxy-4pyridon monobactam inhibitor of AmpC $\beta$ lactamases. Journal of Antimicrobial Chemotherapy. 2000;45:105-9.

[13]. Nukaga M, Kumar S, Nukaga K, Pratt RF, Knox JR. Hydrolysis of third-generation cephalosporins by class $C \beta$-lactamases structures of a transition state analog of cefotaxime in wild-type and extended spectrum enzymes. Journal of Biological Chemistry. 2004;279:9344.

[14]. Jacobs MR, Abdelhamed AM, Good CE, Rhoads DD, Hujer KM, Hujer AM, Domitrovic TN, Rudin SD, Richter SS, van Duin D, Kreiswirth BN. ARGONAUT-I: activity of cefiderocol (S-649266), a siderophore cephalosporin, against gramnegative bacteria, including carbapenem-resistant nonfermenters and Enterobacteriaceae with defined extended-spectrum $\beta$-lactamases and carbapenemases. Antimicrobial agents and chemotherapy. 2019;63:e01801-18.

[15]. Gould IM, Bal AM. New antibiotic agents in the pipeline and how they can help overcome microbial resistance. Virulence. 2013;4:185-91.

[16]. Basmaci R, Bielicki J, Daniels R, Kissoon N, Ellis S, Balasegaram M, Sharland M. Management of children with multidrug-resistant sepsis in lowincome and middle-income countries. The Lancet Child \& Adolescent Health. 2018;2:8-10.

[17]. Ito A, Sato T, Ota M, Takemura M, Nishikawa T, Toba S, Kohira N, Miyagawa S, Ishibashi N, Matsumoto S, Nakamura R. In vitro antibacterial properties of cefiderocol, a novel siderophore cephalosporin, against Gram-negative bacteria. Antimicrobial agents and chemotherapy. 2018;62:e01454-17.

[18]. Ruppé É, Woerther PL, Barbier F. Mechanisms of antimicrobial resistance in Gram-negative bacilli. Annals of intensive care. 2015;5:21.

[19]. McPherson CJ, Aschenbrenner LM, Lacey BM, Fahnoe KC, Lemmon MM, Finegan SM, Tadakamalla B, O'Donnell JP, Mueller JP, Tomaras AP. Clinically relevant Gram-negative resistance mechanisms have no effect on the efficacy of MC-1, a novel siderophore-conjugated monocarbam. Antimicrobial agents and chemotherapy. 2012;56:6334-42.

[20]. McNamara DJ. The fifty year rehabilitation of the egg. Nutrients. 2015;7:8716-22.

[21]. Giansanti F, Leboffe L, Pitari G, Ippoliti R, Antonini G. Physiological roles of ovotransferrin. Biochimica et Biophysica Acta (BBA)-General Subjects. 2012;1820:218-25.

[22]. Price NC, Nairn J. Exploring proteins: a student's guide to experimental skills and methods. Oxford, UK: Oxford University Press; 2009.

[23]. Hopkins FG. On the separation of a pure albumin from egg-white. The Journal of physiology. 1900 ;25:306.

[24]. Chick H, Martin CJ. The precipitation of eggalbumin by ammonium sulphate. A contribution to the theory of the "salting-out" of proteins. Biochemical Journal. 1913;7:380.

[25]. H Wu J. Eggs and egg products processing. Food processing: Principles and applications. $2014 \mathrm{Apr}$ 7:437-55.u S,

\section{Cite this article as:}

Sampath Kumar G, Anitha, Preethi L, Arunkumar R, Ilakkiya A, Selvakumar $K^{*}$ (2020). Isolation, Purification and Antimicrobial Efficacy of Ovotransferrin from Eggs of Broiler, Domestic and Quail, International Journal of Scientific Research in Science and Technology 7 (3): 405 $-413$ 